\title{
Józef Życiński jako filozof i człowiek
}

PROF. DR HAB. JAN WOLEŃSKI

Uniwersytet Jagielloński

Na początku 1980 roku odwiedziłem prof. Izydorę Dąmbską. Pokazała mi pokaźny maszynopis i powiedziała, że jest to książka Józefa Życińskiego, młodego księdza, poświęcona językowi i metodzie. Miała napisać recenzję tego projektu wydawniczego dla Wydawnictwa „Znak”. Nie była w pełni usatysfakcjonowana recenzowanym tekstem. Powiedziała coś w stylu: „Interesujące, ale autor stawia zbyt odważne i ogólne tezy". Pani Izydora była zwolenniczką tzw. małej filozofii w duchu analitycznym, a więc zajmowania się konkretnymi problemami, a nie wielką metafizyką. Niemniej jednak od razu zastrzegła, że recenzja będzie pozytywna, m.in. dlatego, że podziwia niezwykłą erudycję autora. Trudno ocenić z perspektywy tylu lat, czy spotkałem się z nazwiskiem Życińskiego przed wizytą u Dąmbskiej. Jak by nie było, tak to pamiętam, jak wyżej opisałem. Poznaliśmy się później, zapewne na przełomie lat 1981/1982, być może za pośrednictwem Jana Widackiego lub Krzysztofa Gurby. Skoro już jestem przy tym drugim 
nazwisku, to dodam, że zastąpiłem Życińskiego jako promotor doktoratu Gurby. Faktycznie Józef był promotorem, ale jego habilitacja w Papieskiej Akademii Teologicznej nie była uznawana przez władze i z tego powodu nie mógł kierować pracami doktorskimi. Życiński, jak wiadomo, był aktywnym publicystą w czasie stanu wojennego. Władze wpadły na pomysł, dość dziwaczny z uwagi na tradycję cenzury w PRL, aby zaznaczać cenzorskie ingerencje w wydawanych książkach i czasopismach. Zdarzyło się, że pod nazwiskiem Józef Życiński pojawiła się takowa ingerencja. Zapytałem go wtedy, cóż takiego było pod nazwiskiem, że cenzor musiał interweniować. Odpowiedział, że nic specjalnego, mianowicie afiliacja PAT, a używanie tej nazwy było zakazane.

Wspomniana książka Język i metoda ukazała się na początku 1982 roku. Zaraz ją przeczytałem. Dąmbska miała racje. Życiński stawiał ogólne i radykalne tezy, ale taki miał temperament filozoficzny. Nie unikał wielkich problemów metafizycznych, epistemologicznych, metodologicznych i aksjologicznych. Michał Heller mówił dzisiaj o Życińskiego fascynacji matematycznością Wszechświata. To bardzo dobry przykład głębokiej kwestii metafizycznej, rozważanej przez Życińskiego. Był oczywiście filozofem katolickim. Z drugiej strony wyraźnie oddzielał filozofię od światopoglądu. Nie w tym sensie, że kwestionował możliwość fuzji nauki i religii, gdyż wierzył w możliwość racjonalnej rekonstrukcji teizmu w postaci jakiejś wersji teorii Inteligentnego Projektu. Nie dzielił z góry filozofów na 
wierzących i niewierzących, chociaż, czemu trudno się dziwić, cieszył się, że jest sporo tych drugich. Pamiętam, z jakim zadowoleniem prezydował spotkaniu (miało miejsce w Krakowie) z Alvinem Plantingą, kalwinem z denominacji religijnej, filozofem znanym $\mathrm{z}$ analizy dowodów na istnienie Boga i obrońcą koncepcji Inteligentnego Projektu. W ogólności można powiedzieć, że Życiński był za pluralizmem filozoficznym.

Życiński miał swoje zdecydowane sympatie i antypatie filozoficzne. Cenił Whiteheada za odwagę metafizyczną, Kołakowskiego za uczciwość w traktowaniu własnego życiorysu ideowego, ale także za zrozumienie dla problemów transcendentalnych, Poppera za program racjonalnej rekonstrukcji nauki i jej historii, Camusa za wyjątkową czystość moralną. A przecież Popper i Camus byli ateistami, a stosunek Kołakowskiego do religii był niejednoznaczny. Logiczni empiryści byli szanowani przez Życińskiego za profesjonalizm, ale zarzucał im lekceważenie metafizyki. Nie znosił Sartre'a, nie tyle za ateizm, ale za mieszanie filozofii i polityki, oraz postmodernizmu za mętność. Nowy ateizm Richarda Dawkinsa uważał za zbyt prymitywną refutację religii. Ale też nie lubił tomizmu, z wzajemnością zresztą. Kiedy Stefan Świeżawski, profesor KUL i wybitny tomista, otrzymał doktorat honorowy na UJ, na ceremonii wręczenie nie pojawił się nikt z PAT. Zapytałem Józefa, czy to nie aby demonstracja. Odrzekł: „Ty to powiedziałeś", ale uśmiech towarzyszący tym słowom wyrażał przytaknięcie. Gdy został metropolitą lubelskim, od 
razu pomyślałem, że ładnie go urządzili. Dawał sobie jakoś radę, ale wiadomo, że stosunki pomiędzy nim, Wielkim Kanclerzem KUL, a tą uczelnią były dość skomplikowane. Moja pozycja była raczej średnia w kontinuum ocen Życińskiego. Traktował mnie jako kogoś nazbyt zbliżonego do neopozytywizmu, co było minusem w jego oczach, ale, z drugiej strony, nie byłem całkiem zdemoralizowany, gdyż nie miałem nic przeciwko temu, że inni poszukiwali głębi metafizycznej.

Życiński był urodzonym i ostrym polemistą. Ponoć żałował, że cięte riposty nie przystoją biskupowi. Ale i jako hierarcha nie szczędził polemicznych razów. Bywało, że przesadzał. W książce Wszechświat i filozofia (napisanej wspólnie z Hellerem) są dość kąśliwe uwagi o Russellu, np. że poświęcił kilkaset stron w Principia Mathematica, aby przygotować dowód prostego twierdzenia arytmetycznego (wyczuwam w tym bezpodstawną ironię), czy że córka filozofa została bodaj zakonnicą (zabrzmiało to wręcz jak wyraz triumfu: „A widzisz, ateisto”; trzeba jednak dodać, że z uznaniem jest wspomniane to, iż Russell pomagał córce w działalności charytatywnej). Życiński powtarzał plotki o rzekomym nawróceniu Sartre’a, dając im wiarę. W swojej książce Wiara wątpiących przytoczył opinię Dawkinsa o jego zdziwieniu uznaniem teorii ewolucji przez Jana Pawła II. Ponieważ wydało mi się to mało prawdopodobne, napisałem do Dawkinsa, a ten odpowiedział, że nic podobnego nie miało miejsca, natomiast byłby wielce zdziwiony, gdyby papież nie uznał teorii ewolucji. Moja 
książka Granice niewiary jest odpowiedzią na Wiarę wątpiq̨cych, też niewolną od ostrych replik. Starliśmy się także na jednym z posiedzeń Komisji Filozofii Nauk Przyrodniczych PAU. Niemniej jednak Józef oddzielał polemiki, nawet najostrzejsze, od relacji osobistych. Jakoż zawsze pozostawaliśmy w bardzo dobrych, a nawet przyjacielskich stosunkach.

Życińskiego jako człowieka bardzo dobrze charakteryzuje jego znane powiedzenie „Jestem Józef, wasz brat” skierowane do kleryków diecezji tarnowskiej, gdy objął urząd tamtejszego biskupa. To dało asumpt nie tylko do tytułu wybranych prac Życińskiego, ale także do innego „Zobaczyć w innym brata”. I taką postawę reprezentował wobec Innych (celowo użyłem dużej litery), bez względu na narodowość, kolor skóry, wyznanie, zawód, pozycję społeczną, płeć, wiek czy poglądy. I jeszcze raz opowiem historyjkę pro domo sua, o ile wiem, znaną wielu osobom. Jest rok 1982 rok, stan wojenny w pełnej krasie. Zostałem zawieszony w zajęciach dydaktycznych (pracowałem wtedy na Politechnice Wrocławskiej). Wiedziałem, że do ministerstwa skierowano wniosek o zwolnienie mnie z pracy (byłem docentem, rektor nie mógł mnie zwolnić bez zgody ministra). Krążyły pogłoski o spodziewanej czystce i kierowaniu pasożytów, tj. osób nigdzie niepracujących, do reedukacji w specjalnych obozach (ponoć jeden nawet budowano na Żuławach). Gdy spotkałem się z Józefem w Krakowie i nie ukrywałem swoich obaw, powiedział: „Nie przejmuj się, Janie, najwyżej będziesz uczył w seminariach 
duchownych". Zdziwiłem się i zapytałem, czego ateista może nauczać kleryków, a Życiński odpowiedział ze śmiechem: „Przecież będziesz uczył metodologii, nie teologii”. A że sytuacja była poważna, niech o tym świadczy fakt, że prof. Klemens Szaniawski zatrudnił Adama Michnika, także kandydata do reedukacji, jako swego sekretarza. Ponieważ inni mówcy zilustrowali życzliwość Życińskiego wieloma przykładami, nie będę tego wątku rozwijał.

Józef Życiński był wybitnym filozofem, intelektualistą i hierarchą Kościoła katolickiego. Był także człowiekiem z krwi i kości. Lubił brylować w towarzystwie i być ośrodkiem zainteresowania. Cieszyły go wyjazdy zagraniczne i kontakty z wybitnymi filozofami, o których to relacjach mówił z wielką satysfakcją. Nie ukrywał, że zależy mu na karierze osobistej, naukowej i kościelnej. Nie powiadał, jak wielu innych: „Wiesz, chętnie nie zgodziłbym się na bycie biskupem, ale nie wypadało mi odmówić". Chciał być kimś, wszędzie tam, gdzie los go rzucił. Jednocześnie był człowiekiem wyjątkowo otwartym i bezpośrednim. Nie miał nic przeciwko bruderszaftom i sam je chętnie proponował. Jan Widacki organizował seminaria metodologiczne w Chęcinach pod Kielcami. Życiński był tam stałym gościem i był po imieniu z większością uczestników, także z oficerami z Biura Kryminalistycznego Komendy Głównej MO. W połowie lat osiemdziesiątych odbyła się w Osieczanach pod Myślenicami międzynarodowa konferencja metodologiczna. Życiński zaimprowizował niedzielną Mszę św. Słowo „zaimprowizował” jest jak najbardziej 
właściwe, gdyż nie było żadnych, by tak rzec, parafernaliów liturgicznych. Msza została odprawiona po angielsku z uwagi na gości zagranicznych, których było zresztą niewielu i bynajmniej nie byli katolikami. Trudno nie odnieść wrażenia, że był to swoisty popis ze strony Życińskiego, ale najważniejsze, że w dobrym stylu.

Mówiło się o tym, że brano go pod uwagę jako kandydata na przewodniczącego Konferencji Episkopatu Polski, ale było to tylko myślenie życzeniowe tych, którzy sądzili, że młody i otwarty hierarcha mógłby nieco odmienić dość konserwatywne oblicze polskich biskupów. Nie jest zresztą wcale pewne, że miałby taki zamiar. Wprawdzie przypisywano mu liberalizm, czy nawet permisywizm, ale nie ma najmniejszych wątpliwości, że Życiński był lojalnym człowiekiem Kościoła katolickiego. Miał swoje zdanie w wielu sprawach, ale kościelne nauczanie traktował bardzo poważnie. Solidaryzował się nawet z okazjonalnymi poczynaniami politycznymi Kościoła, np. poparł Wałęsę w wyborach prezydenckich w 1990 roku, chociaż niewykluczone, że jako intelektualiście było mu bliżej do Mazowieckiego. Mogło być właśnie tak, iż opowiedział się za Wałęsą z uwagi na stanowisko Episkopatu. Pewnie nie ze wszystkim zgadzał się, np. z wypowiedzią pewnego hierarchy, że Polak głosuje na Polaka, a Żyd na Żyda, ale nie ukrywał swoich ówczesnych preferencji politycznych. I dlatego nie jest łatwo odpowiedzieć na pytanie, niekiedy zadawane, jak arcybiskup (a może nawet już kardynał) Józef Życiński zachowałby się dzisiaj, tj. na początku 2016 roku. Czy tak 
jak bp Tadeusz Pieronek, nieszczędzący słów krytyki pod adresem zwycięzców wyborów w 2015 roku, czy też jakoś inaczej? Mam jednak wrażenie, że gdyby usłyszał o awansach jasnogórskich paulinów wobec kibiców piłkarskich jako przyszłości narodu w XXI wieku, uśmiechnąłby się ironicznie i powiedział: „Niech ojcowie paulini przeczytają Potęgę smaku Herberta”.

Media - Kultura - Dialog. W piąta rocznicę śmierci arcybiskupa Józefa Życińskiego, red. ks. R. Nęcek, ks. W. Misztal, Kraków 2017, s. 131-138.

DOI: http://dx.doi.org/10.15633/9788374385848.12 